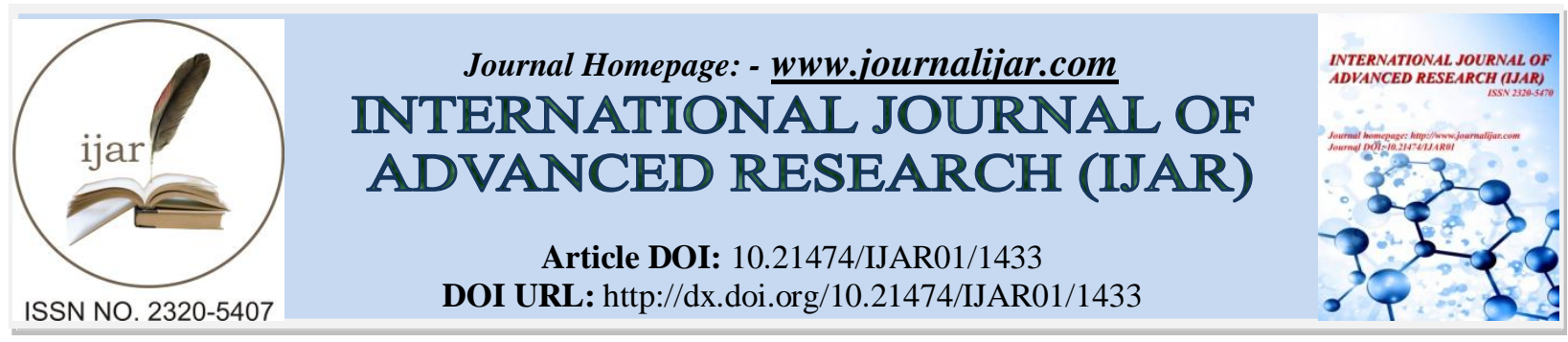

RESEARCH ARTICLE

\title{
MARKETING CONCEPT AND CONSUMERS' SATISFACTIONIN THE NIGERIAN BANKING INDUSTRY: AN ASSESSMENT.
}

Adebowale Biodun Areo, Ph.D, Department of Management Science, Wesley University of Science and Technology, Ondo, Nigeria.

\section{Manuscript Info}

Manuscript History

Received: 12 June 2016

Final Accepted: 19 July 2016

Published: August 2016

Key words:-

Consumer Satisfaction, Marketing, Marketing Philosophy, Positioning, Segmentation, and Targeting.

\section{Abstract}

The paper assessed the application of marketing concept and its variables namely, segmentation, targeting and positioning, in the Nigerian banking industry. It aimed at determining the effect of applying these concept variables on consumers' satisfaction. The study employed questionnaire to draw relevant information. Through the use of stratified random sampling methods, Six hundred and eighty respondents were selected from bank workers and bank customers. This comprises of banks' customers was 340, and bankers 340 respondents were consumers of the bank. The data collected was analyzed using percentages, frequency counts, standard deviation, and mean score. Hypothesis was also postulated and tested using Pearson Correlation, Analysis of Variance, (ANOVA) Duncan Multiple Range Test and Linear Regression. Results showed that targeting had a positive and significant effect on consumer's satisfaction $(\mathrm{t}=2.64 ; \mathrm{p}<$ 0.05). However, though positioning had a positive effect on consumers' satisfaction, it was not significant $(\mathrm{t}=0.56 ; \mathrm{p}>0.05)$. Also, segmentation had a negative but no significant relationship with consumers' satisfaction $(\mathrm{t}=-0.03 ; \mathrm{p}>0.05)$. Results further show that though banks were applying marketing concept, the views of bankers were different from banks customers'. The paper concluded that fierce competitionheightened the interest of banks to target profitable customers by delivering the desired satisfaction better than their competitors through the application marketing concept.

Copy Right, IJAR, 2016,. All rights reserved.

\section{Introduction:-}

Quite a number of researchers have given their views as to how marketing philosophies shape the way for banks to obtain maximum profits by acquiring satisfied customers, developing and retaining customers. Surveys carried out several years ago in the United States, Great Britain and Europe; conclude that the application of marketing philosophies proved successful though with initial resistance by bank managers (Berry, 1982; Yorke, 1982; Oni, 2000; Nunnally, et al. 2000). In the same vein,Median (1983), many years agocarried out, a study on the roles of marketing management in banking. He asserts that banking institutions ought to have adopted the practice and techniques of marketing concepts. The reason he adduced wasthe intense competition, not just from other banks, but other financial institutions such as insurance companies, finance houses, among others, and the increased cost of meeting consumers' needs profitably. The above assertion still holds sway in the Nigerian banking industry as enunciated in the study carried out by Areo (2015). 
The marketing concept holds that achieving organizational goals depends on determining the needs and wants of target markets and delivering the desired satisfaction more effectively and efficiently than competitors do. Interestingly, this concept is a relatively recent business philosophy, when compared with other business philosophies. Many successful and well-known global companies have adopted the marketing concept. The marketing concept is a philosophy of consumer service and mutual gain.

According to Kotler, et al. (1999), Kotler and Armstrong (2006) and Kotler \& Keller (2012), the practice of marketing concept leads the economy by an invisible hand to satisfy the many and changing needs of millions of consumers. To achieve organizational goal, marketing organizations go through a process of target marketing consisting of three variables, namely: market segmentation, market targeting and market positioning.

Target Marketing, from the point of view of Kotler and Armstrong (2006)is a market that consist of buyers and these buyers differs in one or more ways. The buyers are too numerous, and so are their wants, resources, locations, buying attitudes, and buying practices. In view of this, different banks ought todesign a better means of serving certain segments of the market. In the past, sellers do not like this idea or philosophy but prefer mass marketing and product-variety marketing towards target marketing. Target marketing tends to help sellers find marketing opportunities better. The sellers in this case develop the right product for each target market,adjust their prices, distribution channels and advertising to reach target market efficiently. Instead of scattering their marketing effort known as the short-gun approach, they can focus it on the buyers who have the greatest purchase interest also designated as riffle approach.

Target marketing calls for three major steps. The first is market segmentation, which involves dividing a market into distinct groups of buyers who might call for separate products or marketing mixes. The company, according to Palmer (1998),Kotler and Keller (2006), andAnyanwu, (2010) identify different ways to segment the market and develop profiles of the resulting market segments. The second step is market targeting, evaluating each segment's attractiveness and selecting one or more of the market segments to enter. The third step is market positioning, which is about setting the competitive positioning for the product and a detailed marketing mix.

Market Segmentation is an attempt to solve the challenges marketing organizations face in a highly competitive market situation, which is the inability to identify and develop market segments that often lead to failure to achieve organization objectives, or, at least, result in a less effective performance than that of more alert competitors. It is disturbing that many organizations, however, seemingly still do not understand the practical significance of market segmentation, preferring either to try to be all things to all people, or in other cases, attempting to sell to so-called 'market segments,' which are in reality based on a definition of the product or service being offered. This is one of the several reasons why this study was carried out.

\section{Literature Review:-}

According to Hunt (2006), and Kotler and Keller (2006), market segments should satisfy three criteria. They should, first of all, be measurable. Thus, market segments based on traditional geographic, demographic, or socio-economic variables are relatively cheap and easy to measure from published data sources, albeit that such source does become out of date. Market segments based on 'personality' or user behavioural variables are less easy to quantify and are relatively expensive to identify given the necessity to carry out the requisite field surveys. The second criterion is that each segment should be accessible. Such accessibility implies cost-effectiveness. Mass media advertising may well reach a chosen market segment, but at a great cost. Consideration need to be given to finding other methods of communicating with the target group at a lower cost. Again, the more qualitative, the less quantitative the segment, the more difficult it becomes to adopt such a cost-effective approach. Thirdly, each segment should be substantial, that is large enough to be worthy of consideration. Perhaps, a better term might be 'viable' because certain segments may only display viability at some future date, for example student.(Osuagwu 2010)

According to Dublow (1992), Oboh (2002), Lees (2005) and Oke (2012), the advantages to be gained by adopting a strategy of market segmentation or target marketing are many. For example, the organization is committing its limited resources efficiently, that is, it is attempting to maximize its income for a given outlay. This strategy will enable organizations to spot opportunities in the market place, or enable them to capitalize much quicker(Umoren (2006) Uppal,(2010), and Ramesh (2013) The whole ethos of the organization will become outward looking, attempting to achieve its own objectives by giving consumer satisfaction and developing consumer loyalty,(Giese (2000), Gruca and Rego (2005) and Gan, Cohen, Clemes, and Chong (2006). The consumer is central to the 
adoption of a strategy based on market segmentation and too many organizations still attempt to fit the consumer to the existing product or service by remaining inward looking, basing their approach on a definition of a product or products, rather than on market needs.(Ebong (2006), Somoye (2008) and Uppal (2010).

A primary basis for segmentation would be the classification of consumer whether personal or corporate. Almost all organizations, be it a major joint stock company or a local parent-teachers association, will maintain a current bank account of some kind. More interestingly, opined Adedipe (2000) a basis for segmentation may reflect the "management" structures of an organization, whether the demand for financial services is the responsibility of one person - the treasurer or of a number of interested parties or the decision-making unit. Some of who may adopt a positive and others negative attitude towards such services.

Market Targeting immediately follows once an organization has evaluated market segments; it can enter one or many segments of a given market. A company with limited skills or resources might decide to serve only one or a few special segments. This strategy limits sales but can be very profitable. On the other hand, a company might choose to serve several related segments, perhaps those that have different kinds of consumers but with the same basic wants. Or a large company might decide to offer a complete range of products to serve all the market segments. Most companies enter a new market by serving a single segment, and if this proves successful, they add segments (Kotler, et al. 1999, Kotler and Keller 2012).

A product's position is the way the product is defined by consumers on important attributes; it is the place the product occupies in consumers' mind relative to competing products. A firm's competitive advantage and its product's position can be quite different. A competitive advantage is the strength of a company, while a product's position is a prospect's perception of a product(Afolabi (2004), and Asikhia (2010) A competitive advantage, like low costs or high quality, could influence a product's position; but in many cases, it is not central to it. Consumers are overloaded with information about products and services. They cannot evaluate products every time they make a buying decision. To simplify buying decision making, consumers organize products into categories - that is, they 'position' products, services and companies in their minds.

A product's position affirm Elumelu (2004) and Bello, Chama, and Abba (2006) is the complex set of perceptions, impressions and feelings that consumers hold for the product compared with competing products. Consumers position products with or without the help of marketers. But marketers do not want to leave their product's position to chance. They plan positions that will give their products greatest advantage in selected target markets, and design marketing mixes to create these planned positions.

According to Ries and Trout (2000), positioning is popularized by advertising executives. They see it as a creative exercise done with an existing product. Positioning starts with a product, a piece of merchandise, a service, a company, an institution or even a person. But positioning is not about what you do to a product; positioning is what you do to the mind of the prospect. That is, you position products in the mind of the prospect. (Gruca and Rego (2005 and Gan, Cohen, Clemes, and Chong (2006) They argue that current products generally have a position in the minds of consumers and further show how familiar brands can acquire some distinctiveness in an overcommunicated society, where there is so much advertising that consumers screen out most of the messages. They acknowledge that the positioning strategy might call for changes in the product's name, price and packaging, but these are cosmetic changes done for the purpose of securing a worthwhile position - in the prospect's mind. This study was interested in finding out the extent to which Nigerian banking industry apply the variables of marketing concept namely segmentation, targeting and positioning.

\section{Research Problem:-}

One of the majorobservations of this studylies in the fact that theextenttowhichNigerianbankshave showninterestintheapplicationofmodern marketing practicesisstillunknown.Majority of Banksin Nigeria arestill largely practicingsellers'market. There is lowbanking habit among Nigerian formal and informal sector workers.Banksservicesare observablyavailable, butwereclonesfromotherbanksandare unaffordable(Areo, 2007, and Oni,2013).To date,littleornoresearchhasbeendoneinthis partofthe world to determine theexistingrelationship between the applicationof marketing philosophiesandconsumers'satisfaction.Virtually allknownstudieson marketing principlesandpracticesinbanksthathavebeenreportedinliteratureswere carriedoutin Brazil,America,Japan,Mexicoandother developedcountries. 
InBrazil,consumers experienced dissatisfactioninthebanking industry generally. In its quest to finding solution, Brazil'sbankingindustryadopted the principleofmarketingphilosophies especially marketing concept. Theapplication,according toWash,(2006)broughtabouthighpatronage ofbankservicesand products. Banks in Nigeria are producing product that are generic in nature without recourse to individual needs and wants which differ markedly. Budgetary allocations for advertisement by banks which ought to position banks' products are continuously deceasing. In the same vein, targeting profitable bank consumers rather than satisfying them has remained the preoccupation of banks. The need to assess the application of marketing concept in banks is expedient because consumers are becoming moreinformedanddemanding;consequently,their qualityexpectations havebeen raised bythe practices of superiorretailers (Nweke, 1991).

The objective of this paper therefore is as stated below.

\section{Research Objectives:-}

The purpose of the study was to assess Nigerian banks' application of marketing concept with a view to satisfyingthe needs and wantsof their customers. Specifically it was to determine the application of marketing concept variables namely, segmentation, targeting, and positioning.in selected Nigerian banks. Other objective was to ascertain the impact of applying these marketing concept variables on consumers' satisfaction. The paper thus seeks to provide answers to the following questions:

1. What are the major marketing strategies adopted by banks in coping with the emergent competition in the industry?

2. What marketing performance measures are used in evaluating the effectiveness of marketingconcept strategies?

3. To what extent have banks in Nigeria adopted marketing concept strategies impacted on bank marketing performance?

4. iv, Arebanksactuallyapplyingmarketingpracticestothesatisfactionoftheirnumerous consumers?

5. .Can consumers trulyhave100 percent satisfaction?

6. Arebanks'thoughtsconcerningtheirservicedeliveryagreeingwithconsumers'ideof services?

7. vii.. Areconsumers'valueandesteemimprovedthroughthe application of marketing concept,

\section{Methodology:-}

The study was carried out in Asokoro District of Abuja, the Federal Capital of Nigeria.Ten out ofNigerian'sconsolidated banks coincidentally represented here, were purposively selected for the study. The study initially held a number of focus group discussions to confirm existing perception and pre-conceptions gathered from background reading. This was to assess the validity of pursuing certain area of enquiry, lending to generation of ideas in line with Lewis' (1982) method. The discussions proved invaluable in chatting possible course and guidelines for a structured survey questionnaire, which included perceptional statements and throwing up possible areas of problems in using the survey questionnaire. The population of staff ofbanks was 2,850 from which 340 were selected and an equivalent number, 340 customers were selected from a population of 3,210 obtained through traffic count and consumer cycle per week.

Questionnaires were used to collect information from bank workers, and the banks' clients. A test and pre-test were conducted in banks other than ones under study to validate the instruments used. In the analysis of data, both descriptive and inferential statistical tools were employed. Frequency distribution, percentages, means, and standard deviation were used to describe and characterize the observations.

Statistical graphs such as histograms, bar charts etc., highlighted the relationship between variables. The hypothesis postulated was tested using Pearson Correlation and Linear Regression Analysis. The hypothesis postulated in the study area was tested using the following tools, Pearson Correlation, Analysis of Variance (ANOVA), Duncan Multiple Range Test (DMRT) and linear regression. The hypothesis was to determine the significance and magnitude of association that exist between variables of interest, that is, the possible differences or relationships between two or more variables. They determine the strength and direction of linear relationship that exists among the variables. The amount of variation was also specifically tested.Inthesamevein,thefollowingdayswereobservedtobeideal fortheadministeringof thequestionnaires, they wereMondays, WednesdaysandFridays, as humantrafficonthesedayswere exceptionallyhigh.Thetentopbanks were UnitedBankfor Africa(UBA);firstBank;ZenithBank;Guaranty TrustBank(GTB);EcoBank;SkyeBank; Diamond 
Bank; Sterling IBTCBank; and Equatorial Trust Bankas seen intable1.

\section{Findings and Discussions:-}

Table 2 shows the distribution of banker respondents by their level of agreement on the application of marketing concept by banks. There are three components of marketing concept namely, segmentation, targeting and positioning. Findings reveal that bankers were of the opinion that their banks were applying marketing concept components. This was observed from the mean scores of segmentation variables, such as demographic, psychographic, behavioural, occupational segmentation with the following mean scores 4.32, 3.88, 3.29 and 3.67. The overall segmentation mean score of 3.93, which was above the average of 3.0, implies that the bankers' agreement was high and it connotes that the concept was applied. The most favoured and applied marketing concept component was geographic segmentation with a mean score of 4.32 .

Concerning targeting, this was the most favoured of all the marketing concept components. The mean scores of all targeting sub-variables were higher than those of segmentation, to prove this. These components such as targeting whole market, several market and large share of sub-market had these mean scores of 4.00, 3.77 and 3.85 respectively. The overall targeting mean score of 3.892 was higher than that of segmentation. This implies that targeting as a concept component was applied by all the banks.

Positioning was observed to be the least favoured and therefore least applied of all the marketing concepts. According to the ratings, bankers were affirming that positioning was being applied as a marketing concept component judging from the mean scores of the sub-variables. Among the sub-variables, the positioning of products in terms of giving good impression was most favoured and was considered as the most applied. It had a mean score of 3.89, meaning more bankers agreed it was being applied. Others such as price changing as a strategy had a mean score of 3.70, perception had 3.68 and others were lower. It is instructive that positioning was not being applied as a marketing concept component. Banks should therefore, strategize to ensure their products are well positioned in the heart of their consumers.

Fig. 1 further expatiates on the above views of bank staff on Targeting. As said earlier it was the most favoured and applied, followed by segmentation while positioning was the least favoured and therefore the least applied of these marketing concept component in the reckoning of bank staff.

Conversely, Table 3 shows the distribution of respondents (bank customers) by their rating of marketing concept application by their banks. The customers' views differed slightly with respect to their agreement on the level of application of marketing concept. The mean score of the sub-variables of this concept were lower than was obtained by bank staff. However, targeting was the most favoured by bank customers with a mean score of 3.5, while segmentation and positioning had mean scores of 3.3 each. The average mean scores imply that consumer were not as impressed with the application of marketing concept components in the banks. They agreed that the concept components were being applied but not to their satisfaction. They want banks to move from averagely applying the concept to thestage of highly applying the concept. It is important to note that geographical segmentation was seen as being well applied by both bankers and consumers. It has a mean score of 3.92 which was clearly higher as mean score for all the sub-variables. Ries and Trout (1981) observed that positioning in United States has been used essentially as a communication issue where the nature of a service is given and the objective is to manipulate consumer perception of it. Lovelock (1984) also pointed out that positioning was more than merely advertising and promoting products and services, but involves considerations of pricing, distribution and the nature of the product offer itself, the core around which all positioning strategies revolve.

Fig. 2 makes the views of customers clearer. The most favoured marketing concept componentas targeting (3.5), while segmentation and positioning had equal mean scores. Bank customers would be satisfied if banks would apply the marketing concept as expected, but as it were, they are saying that the concept was not being applied.

With respect to marketing concept, the banker respondents favoured the application of targeting among the components of marketing concept. They scored it with a mean score of 3.9 very close to high, while their consumers counterpart scored average, meaning according to them that the concept was averagely applied; however, it was not high enough. Segmentation was next rated high, but the mean score of 3.7 showed that it was averagely being applied as marketing concept components. Positioning was the least favoured among the three components, the 
mean score by the banker respondents was 3.5 and the mean score for the consumers was 3.3. These are average scores implying that the concept is averagely being applied.

\section{Test of Hypotheses:-}

The hypothesis postulated in the study area was tested using the following tools, Pearson Correlation, Analysis of Variance (ANOVA), Duncan Multiple Range Test (DMRT) and linear regression. The hypothesis was to determine the significance and magnitude of association that exist between variables of interest, that is, the possible differences or relationships between two or more variables. They determine the strength and direction of linear relationship that exists among the variables. The amount of variation was also specifically tested.

Consequently, a hypothesis was postulated as seen below:

\section{Hypothesis Testing and Result:-}

The hypothesis postulated that there is no significant positive relationship between product positioning strategy and attitudes of consumers to patronize products and services. Positioning has no significant correlation with consumers satisfaction because of the correlation value of $\mathrm{R}=0.045$ which is significant at $\mathrm{P} \leq 0.428$. As a result of this, the hypothesis is upheld. The agreement shows that positioning does not influence consumers' satisfaction. Management should not therefore spend more money on this strategy.

The Pearson correlation table obtained as shown in Table 4 also explains the strength and significance of the bivariate relationships between product positioning and attitudes of banks customers. Positioning was postulated as possibly not having any positive relationship between it and attitudes of consumers. The table shows that positioning was not significantly correlated with consumer satisfaction $(\mathrm{R}=0.043 ; \mathrm{P}<0.428)$. As a result of the above, the null hypothesis is upheld. The agreement, shows positioning as a marketing concept variable which does not influence satisfaction of consumers. This suggests that management may not bother to expend much resource on this aspect of marketing concept strategy. Fig 1 shows a near no-trend linear graph. The graph remains parallel notwithstanding what the banks were doing in terms of increasing budgets and their aggressive advertisement strategy. This means the consumers were not getting satisfied at the same pace that banks' management were putting efforts on positioningtheir products.

\section{Regression Results:-}

The results obtained from the estimation of the model is presented in Table 5.... below The Coefficient of Equation on Relationship between Concept Components

\section{Evaluation of relationships between various components of marketing practices and consumers' satisfaction} using Linear Regression Analysis

An attempt at understanding how the application of marketing philosophies and selected socio-economic background of respondents contributed to the variations observed in consumers' satisfaction was carried out using multiple linear regression analysis.

A functional equation of the form $\mathrm{Y}=\mathrm{f}\left(\mathrm{X}_{1}, \mathrm{X}_{2}, \mathrm{X}_{3}, \mathrm{Xn}\right.$, e) was fitted using ordinary least square regression method. Where $\mathrm{Y}=$ (mean consumer satisfaction)

\section{Marketing concept as viewed by bank staff and consumers}

There were three variables used to measure the agreement level of both bank workers and the consumers. These are segmentation, targeting and positioning as shown on Table 3. As with the previous concepts, significant difference exists between the ways the bank workers see market concept and the way the consumers observed it. The bank workers rated segmentation far higher with a mean score and a standard deviation of $3.69+0.38$, while their consumers on this same variable rated it lower with a mean score and standard deviation of $3.30+0.37$. The same observation was for targeting, where the bank workers rated it very high with a mean score and standard deviation of $3.49+0.59$. In rating positioning, the bankers maintain their high score than their consumers. They posted a mean score and standard deviation of $3.59+0.35$, and their consumers gave a mean score and standard deviation of $3.31+$ 0.27. Fig 33 shows that apart from the general lower rating by consumers, both categories rated segmentation and positioning much lower than targeting. 
The above is expected since the bankers would always feel they were doing enough, while the consumers would always be desirous of being satisfied more at all cost using the instrumentality of the three variables - segmentation, targeting and positioning. All the consumers were saying was that more should be done to satisfy their varied needs and wants. Fig. 33 gives an illustration of the opinion of the two groups of respondents. The consumers were again seen with poor agreement scores for all marketing concept components. Although, both scored targeting significantly higher than other components, those of consumers were very low in comparison to those banker respondents.

\section{Conclusion and Summary:-}

The findings on marketing concept application proved that the banksaveragely applied this concept. In general,the consumer respondents again felt that banks can do better on this concept application. The bankers andconsumers' respondents also averagely agree that banks applied marketing concept. However, consumers' ratings were generally low compared to their banker counterparts. Consumers wish that banks would improve on their social responsibilities in the area of parks and gardens, beautification of environment and patronage of banks' services.

\section{Recommendations:-}

Banks should traverse uncommon and uncomfortable terrains to build sales force needed to market their needed services, thereby ensuring consumers' satisfaction.Each bank should endeavor to identify the parts of the market that it can serve best. An aggressive approach that involves holistic marketing or holistic marketing practices is being advocated if consumers' satisfaction would be attained. From the results of findings, the following suggestions are made.

Banks should ensure that their approach to the application of marketing practices get a boost. Although, banks were observed to be applying marketing practices, the results coming from consumers showed that the application requires overhauling and re-engineering if the consumers would be satisfied. On marketing concept, it is very interesting that segmentation was accorded the right place; banks are encouraged to continue to improve on this strategy. However, a lot of work is required in product targeting and product positioning. Banks should increase their budgets on these two strategies, product targeting and positioning to enhance their profit and bring about consumer satisfaction.

Table1:- Distribution and Selection of Bank Workersin Top Ten Banks in the Study Area.

\begin{tabular}{|l|l|l|}
\hline Name of bank & No. of bankers & No. of bank Customers \\
\hline UBA & 370 & 390 \\
Union & 330 & 300 \\
First & 340 & 350 \\
Zenith & 310 & 385 \\
GTB & 290 & 248 \\
Skye & 245 & 272 \\
Unity Bank & 235 & 275 \\
Eco Bank & 237 & 295 \\
Diamond & 250 & 340 \\
WEMA & 243 & 335 \\
\hline Total & 2850 & 3210 \\
\hline
\end{tabular}

Source: Survey 2015 
Table 2:- Distribution of the respondent bank staff by rating of application of Marketing Concepts by the banks.

\begin{tabular}{|c|c|c|c|c|c|c|c|c|c|}
\hline Variable & $\begin{array}{l}\text { Strongly } \\
\text { agreed }\end{array}$ & Agreed & Neutral & Dis & greed & $\begin{array}{l}\text { Str } \\
\text { dis }\end{array}$ & $\begin{array}{l}\text { ngly } \\
\text { greed }\end{array}$ & Mean & $\begin{array}{l}\text { Standard } \\
\text { deviation }\end{array}$ \\
\hline \multirow{7}{*}{$\begin{array}{l}\text { Geographic segmentation } \\
\text { Demographic segmentation } \\
\text { Psychological segmentation } \\
\text { Behavioural segmentation } \\
\text { Segmentation strategy } \\
\text { Occupational segment strategy } \\
\text { State capital as strategy }\end{array}$} & $193 \quad 56.8$ & 21.5 & 18.8 & 10 & 2.9 & 0 & 0 & 4.32 & 0.879 \\
\hline & 39.7 & 23.8 & 20.9 & 53 & 15.6 & 0 & 0 & 3.88 & 1.104 \\
\hline & 2.4 & $162 \quad 47.6$ & $\begin{array}{ll}109 & 32.1 \\
\end{array}$ & 41 & 12.1 & 20 & 5.9 & 3.29 & 0.921 \\
\hline & 17.4 & $150 \quad 44.1$ & $\begin{array}{ll}81 & 23.8 \\
\end{array}$ & 41 & 12.1 & 9 & 2.6 & 3.61 & 0.993 \\
\hline & 2.6 & 59.4 & 20.6 & 49 & 14.4 & 10 & 2.9 & 3.44 & 0.876 \\
\hline & 26.5 & 31.8 & 27.1 & 40 & 11.8 & 10 & 2.9 & 3.67 & 1.080 \\
\hline & 23.8 & $\begin{array}{ll}133 & 39.1 \\
\end{array}$ & 17.4 & 57 & 16.8 & 10 & 2.9 & 3.64 & 1.105 \\
\hline Average segment score & - & - & - & - & & - & & 3.693 & 0.3786 \\
\hline \multirow{3}{*}{$\begin{array}{l}\text { Target whole market } \\
\text { Target several market } \\
\text { Target large share sub-market }\end{array}$} & 11132.6 & $158 \quad 46.5$ & 15.0 & 20 & 5.9 & 0 & 0 & 4.06 & 0.843 \\
\hline & $\begin{array}{ll}55 & 16.2 \\
\end{array}$ & $194 \quad 57.1$ & 14.4 & 42 & 12.4 & 0 & 0 & 3.77 & 0.866 \\
\hline & 26.2 & 13940.9 & 24.4 & 29 & 8.5 & 0 & 0 & 3.85 & 0909 \\
\hline Average Target Score & - & - & - & - & & - & & 3.892 & 0.5255 \\
\hline \multirow{8}{*}{$\begin{array}{l}\text { Positioning perception } \\
\text { Positioning impression } \\
\text { Positioning feelings } \\
\text { Positioning qualities } \\
\text { Positioning change of names } \\
\text { Positioning price changes } \\
\text { Positioning change packaging } \\
\text { Positioning change advert }\end{array}$} & $\begin{array}{ll}81 & 23.8 \\
\end{array}$ & $118 \quad 34.7$ & 32.9 & 9 & 2.6 & 20 & 5.9 & 3.68 & 1.050 \\
\hline & $101 \quad 29.7$ & 11132.6 & $118 \quad 34.7$ & 10 & 2.9 & 0 & 0 & 3.89 & 0.867 \\
\hline & \begin{tabular}{|ll}
30 & 8.8 \\
\end{tabular} & $183 \quad 53.8$ & $\begin{array}{ll}86 & 25.3 \\
\end{array}$ & 41 & 12.1 & 0 & 0 & 3.59 & 0.813 \\
\hline & 25.9 & $120 \quad 35.3$ & 24.4 & 30 & 8.8 & 19 & 5.6 & 3.67 & 1.120 \\
\hline & $\begin{array}{ll}88 & 25.9 \\
\end{array}$ & $\begin{array}{ll}93 & 27.4 \\
\end{array}$ & 26.5 & 59 & 17.4 & 10 & 2.9 & 3.56 & 1.136 \\
\hline & $\begin{array}{ll}110 & 32.4\end{array}$ & $\begin{array}{ll}77 & 22.6\end{array}$ & $\begin{array}{ll}103 & 30.3\end{array}$ & 40 & 11.8 & 10 & 2.9 & 3.70 & 1.129 \\
\hline & $\begin{array}{ll}10 & 2.9 \\
\end{array}$ & $131 \quad 38.5$ & $131 \quad 38.5$ & 39 & 11.5 & 29 & 8.5 & 3.16 & 0.968 \\
\hline & 26.2 & $\begin{array}{ll}71 & 20.9\end{array}$ & $122 \quad 35.9$ & 29 & 8.5 & 29 & 8.5 & 3.48 & 1.208 \\
\hline $\begin{array}{l}\text { Overall mean score and } \\
\text { Standard Deviation. }\end{array}$ & - & - & - & - & & - & & 3.591 & 0.3488 \\
\hline
\end{tabular}

Source: Survey, 2015.

Score: Strongly Agree $=$ = High (5)

Agree $\quad=$ Above Average (4)
Neither Agree nor Disagree $\quad=$ Average (3)

Disagree $\quad=\quad=$ Below average $(2)$

Strongly Disagree = = Low (1)

$\begin{array}{lll}\text { Mean score } & = & =3.0 \pm 1.5811 \\ \text { High } & = & =4.5811 \\ \text { Average } & = & =3.000 \\ \text { Low } & = & =1.4189\end{array}$

Table 3:- Distribution of the respondent bank customers by their rating of the Marketing concepts application by their banks.

\begin{tabular}{|c|c|c|c|c|c|c|c|}
\hline Variable & $\begin{array}{l}\text { Strongly } \\
\text { agreed }\end{array}$ & Agreed & Neutral & Disagreed & $\begin{array}{l}\text { Strongly } \\
\text { disagreed }\end{array}$ & Mean & $\begin{array}{l}\text { Standard } \\
\text { deviation }\end{array}$ \\
\hline & $\mathrm{F} \quad \%$ & $\%$ & $\%$ & $\%$ & $\mathrm{~F} \quad \%$ & & \\
\hline \multirow{6}{*}{$\begin{array}{l}\text { Geographic segmentation } \\
\text { Demographic } \\
\text { segmentation } \\
\text { Psychological } \\
\text { segmentation } \\
\text { Behavioural segmentation } \\
\text { Segmentation strategy } \\
\text { Occupational segment } \\
\text { strategy } \\
\text { State capital as strategy }\end{array}$} & 11332.7 & $\begin{array}{l}133 \\
38.4\end{array}$ & $60 \quad 17.3$ & $\begin{array}{l}40 \\
11.6\end{array}$ & 0 & 3.92 & 0.979 \\
\hline & 0 & $\begin{array}{l}132 \\
38.2\end{array}$ & $\begin{array}{l}135 \\
39.0\end{array}$ & $\begin{array}{l}39 \\
11.3\end{array}$ & $40 \quad 11.6$ & 3.04 & 0.979 \\
\hline & $\begin{array}{ll}70 & 20.2\end{array}$ & $\begin{array}{l}43 \\
12.4\end{array}$ & $\begin{array}{l}153 \\
44.2\end{array}$ & $\begin{array}{l}49 \\
14.2\end{array}$ & $\begin{array}{ll}31 & 9.0\end{array}$ & 3.21 & 1.181 \\
\hline & 0 & $\begin{array}{l}52 \\
15.0\end{array}$ & $\begin{array}{l}183 \\
52.9\end{array}$ & $\begin{array}{l}71 \\
20.5\end{array}$ & $40 \quad 11.6$ & 2.71 & 0.859 \\
\hline & $\begin{array}{ll}103 \quad 29.8 \\
\end{array}$ & $\begin{array}{l}70 \\
20.2\end{array}$ & $\begin{array}{l}70 \\
20.2\end{array}$ & $\begin{array}{l}103 \\
29.8\end{array}$ & $\begin{array}{ll}0 & 0\end{array}$ & 3.50 & 1.202 \\
\hline & 5.8 & $\begin{array}{l}234 \\
67.6\end{array}$ & & $\begin{array}{ll}52 & 15.0\end{array}$ & $\begin{array}{ll}40 & 11.6\end{array}$ & 3.41 & 1.164 \\
\hline
\end{tabular}




\begin{tabular}{|c|c|c|c|c|c|c|c|}
\hline & $\begin{array}{ll}50 & 14.5\end{array}$ & $\begin{array}{ll}84 & 24.3\end{array}$ & $\begin{array}{l}153 \\
44.2\end{array}$ & 14.5 & $\begin{array}{ll}9 & 2.6\end{array}$ & 3.34 & 0.980 \\
\hline AVMCSGSC & & & & & & 3.304 & 0.3676 \\
\hline \multirow{3}{*}{$\begin{array}{l}\text { Target whole market } \\
\text { Target several market } \\
\text { Target large share sub- } \\
\text { market }\end{array}$} & 14.5 & $114 \quad 32.9$ & 10931.5 & 0 & $\begin{array}{ll}73 & 21.1 \\
\end{array}$ & 3.20 & 1.311 \\
\hline & 17.9 & 16848.6 & $\begin{array}{ll}82 & 23.7\end{array}$ & $\begin{array}{ll}34 & 9.8\end{array}$ & 0 & 3.75 & 0.864 \\
\hline & 23.7 & 10129.2 & 10229.5 & $41 \quad 11.8$ & $20 \quad 5.8$ & 3.52 & 1.145 \\
\hline AVMCTGSC & - & - & - & - & - & 3.491 & 0.5926 \\
\hline \multirow{5}{*}{$\begin{array}{l}\text { Positioning perception } \\
\text { Positioning impression } \\
\text { Positioning feelings } \\
\text { Positioning qualities } \\
\text { Positioning change of } \\
\text { names } \\
\text { Positioning price changes } \\
\text { Positioning change }\end{array}$} & $50 \quad 14.5$ & $81 \quad 23.4$ & $\begin{array}{l}143 \\
41.3\end{array}$ & 5215.0 & $20 \quad 5.8$ & 3.26 & 1.063 \\
\hline & 17.3 & $\begin{array}{ll}53 & 15.3 \\
\end{array}$ & 16347.1 & $\begin{array}{ll}70 & 20.2 \\
\end{array}$ & 0 & 3.30 & 0.981 \\
\hline & 11.6 & $\begin{array}{l}108 \\
31.2\end{array}$ & 14441.6 & 5415.6 & 0 & 3.39 & 0.885 \\
\hline & 2.6 & $\begin{array}{l}123 \\
35.5\end{array}$ & 17350.0 & $41 \quad 11.8$ & 0 & 3.29 & 0.704 \\
\hline & $113 \quad 32.7$ & $51 \quad 14.7$ & $74 \quad 21.4$ & $78 \quad 22.5$ & 8.7 & 3.40 & 1.367 \\
\hline \multirow{3}{*}{$\begin{array}{l}\text { Positioning change } \\
\text { packaging } \\
\text { Positioning change advert }\end{array}$} & $71 \quad 20.5$ & $\begin{array}{l}113 \\
32.7\end{array}$ & 11232.4 & $50 \quad 14.5$ & 0 & 3.59 & 0.971 \\
\hline & $\begin{array}{ll}41 & 11.8\end{array}$ & $\begin{array}{l}107 \\
30.9\end{array}$ & 11633.5 & $72 \quad 20.8$ & 2.9 & 3.28 & 1.016 \\
\hline & $\begin{array}{ll}30 & 8.7\end{array}$ & $84 \quad 24.3$ & $\begin{array}{l}129 \\
37.3\end{array}$ & $50 \quad 14.5$ & $\begin{array}{ll}53 & 15.3\end{array}$ & 2.97 & 1.162 \\
\hline AVMCPOSC & - & - & - & - & - & 3.309 & 0.268 \\
\hline
\end{tabular}

Source: Survey, 2015.

Score: Strongly Agree $=\quad=$ High (5)

Agree $\quad=\quad=$ Above Average (4)

Neither Agree nor Disagree = Average (3)

Disagree $=\quad=$ Below average (2)

Strongly Disagree $\quad=\quad=$ Low $(1)$

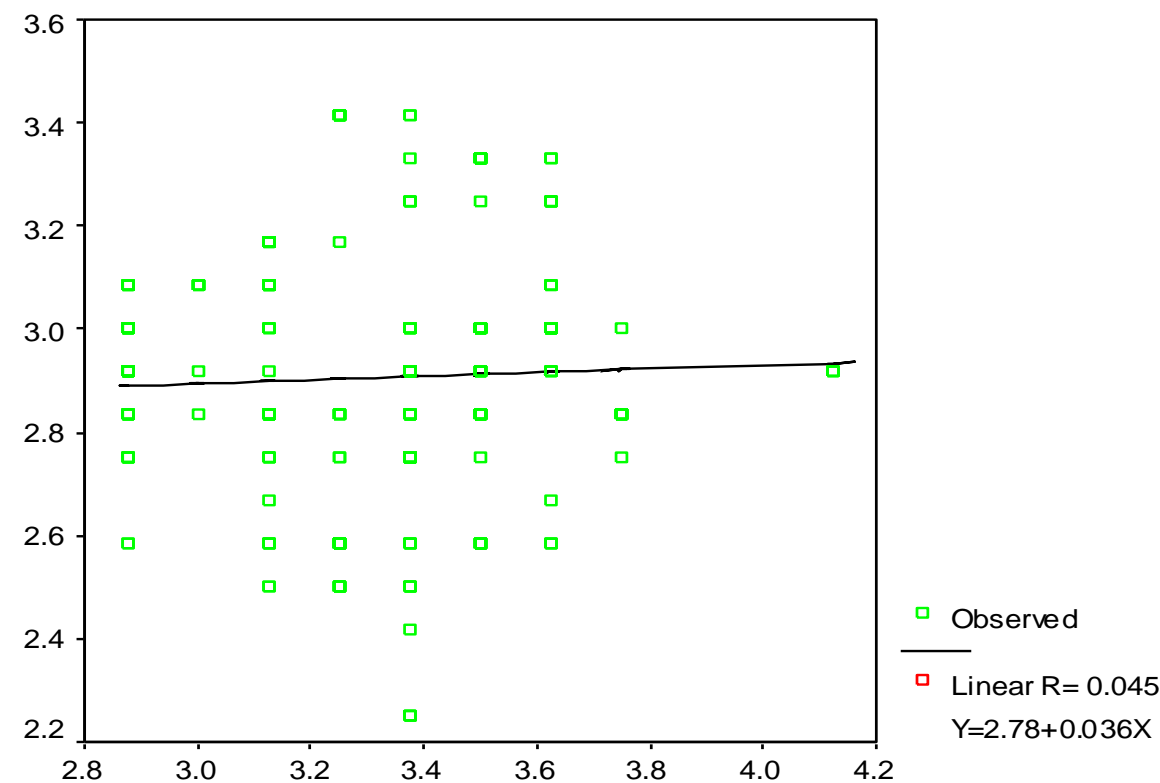

Mean product positioning rating

Fig 1:- Relationship between product positioning and consumer satisfaction. 
Table 4:- Correlation between selected concept variables and consumer satisfaction.

\begin{tabular}{|l|l|l|}
\hline Variables & & Mean Consumer satisfaction \\
\hline $\begin{array}{l}\text { Mean positioning } \\
\text { rating }\end{array}$ & Pearson correlation & $\mathrm{R}=0.043^{* *}$ \\
\cline { 2 - 3 } & Sig. & 0.428 \\
\cline { 2 - 3 } & $\mathrm{N}$ & 346 \\
\hline
\end{tabular}

Source: Survey 2015

* Correlation is significant at the $\mathrm{P}<0.05$ level

** Correlation is significant at the $\mathrm{P}<0.01$ level

Table 5:-

\begin{tabular}{|l|l|l|l|l|}
\hline Model & Unstandardized coefficients & & $\mathrm{t}$ values & Signif. of t \\
\hline $\mathrm{X}_{1}$ & $-9.668 \mathrm{E}-04^{*}$ & .030 & -.032 & .975 \\
\hline $\mathrm{X}_{2}$ & $9.458 \mathrm{E}-02 *$ & .036 & 2.637 & .009 \\
\hline $\mathrm{X}_{3}$ & $1.227 \mathrm{E}-02 *$ & .021 & .572 & .568 \\
\hline
\end{tabular}

\begin{tabular}{|l|l|}
\hline \hline Variables & \\
\hline Mean positioning & Pearson correlation \\
\cline { 2 - 2 } Rating & Sig. \\
\cline { 2 - 2 } & $\mathrm{N}$ \\
\hline
\end{tabular}

Table 6:- Comparative mean ratings of the adoption level of the strategies of marketing concept by bank staff and consumers.

\begin{tabular}{|l|l|l|l|l|l|}
\hline \multicolumn{2}{|l|}{} & Mean value + sd & Positioning & \\
\hline $\begin{array}{l}\text { Category of } \\
\text { respondent }\end{array}$ & $\begin{array}{l}\text { No. } \\
\text { respondent }\end{array}$ & Segmentation & Targeting & P & \\
\hline Bank staff & 340 & $3.69+.38$ & $3.89+.53$ & $3,59+.35$ & \\
\hline Bank consumers & 346 & $3.30+37$ & $3.49+.59$ & $3.31+.27$ & \\
\hline F - value & & 186.814 & 87.76 & 141.194 & \\
\hline Significance & & 0.000 & 0.000 & 0.000 & \\
\hline
\end{tabular}

Means are significantly different at $\mathrm{P}<0.005$

Source: Survey 2014

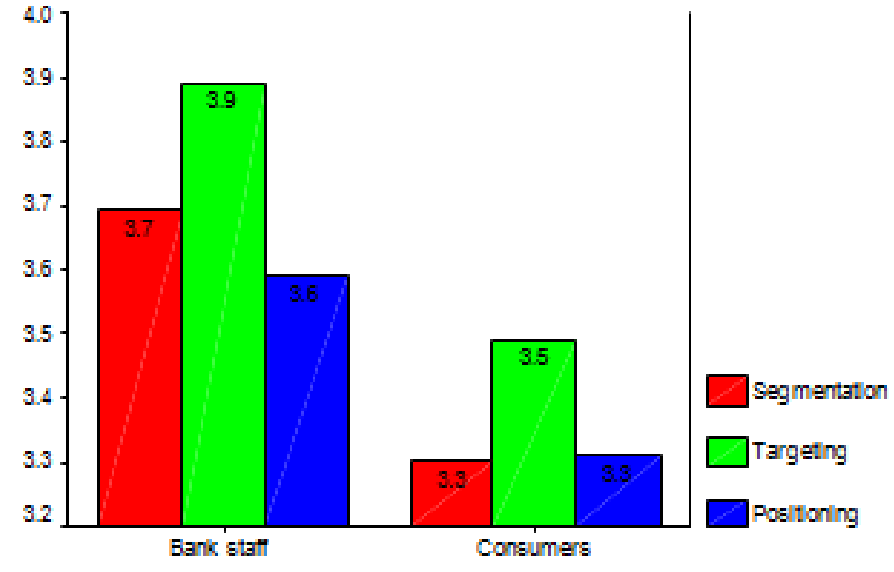

\section{Categories}

Fig 2: Comparatve mean rating of the components of marketing concept

by bank stall and consumers 


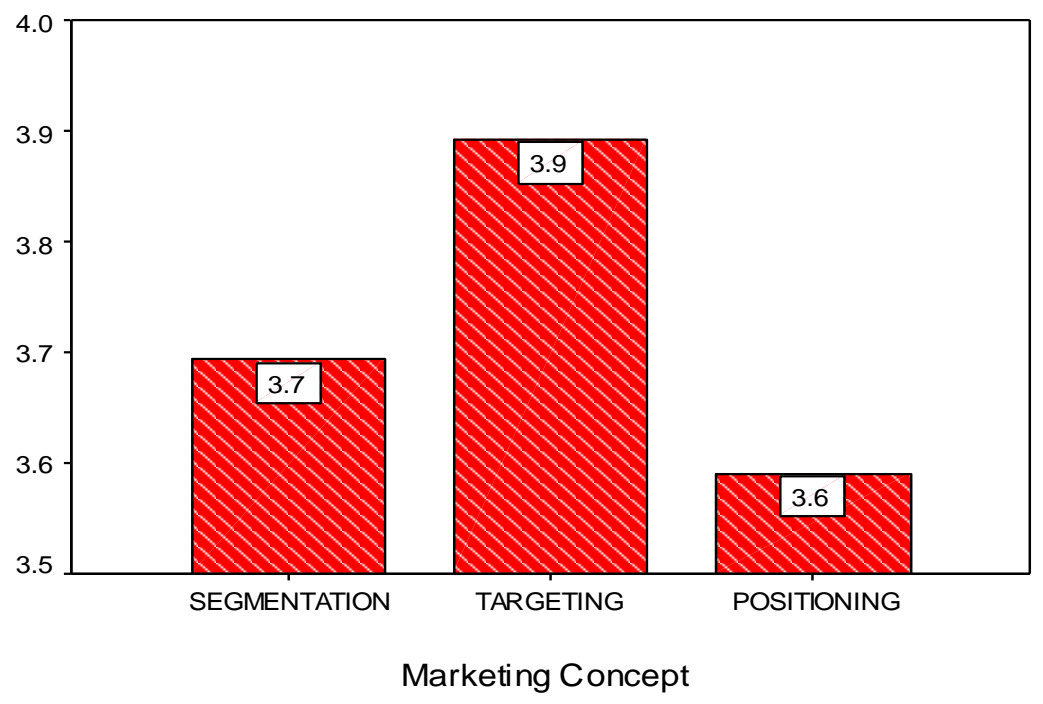

Fig : Bar Chart showing the mean score of respondent

bank staff on the level of adoption of marketing concepts by their banks

Fig. 23:- Bar chart showing the mean score of respondent bank staff on the level of application of marketing concepts by their banks.

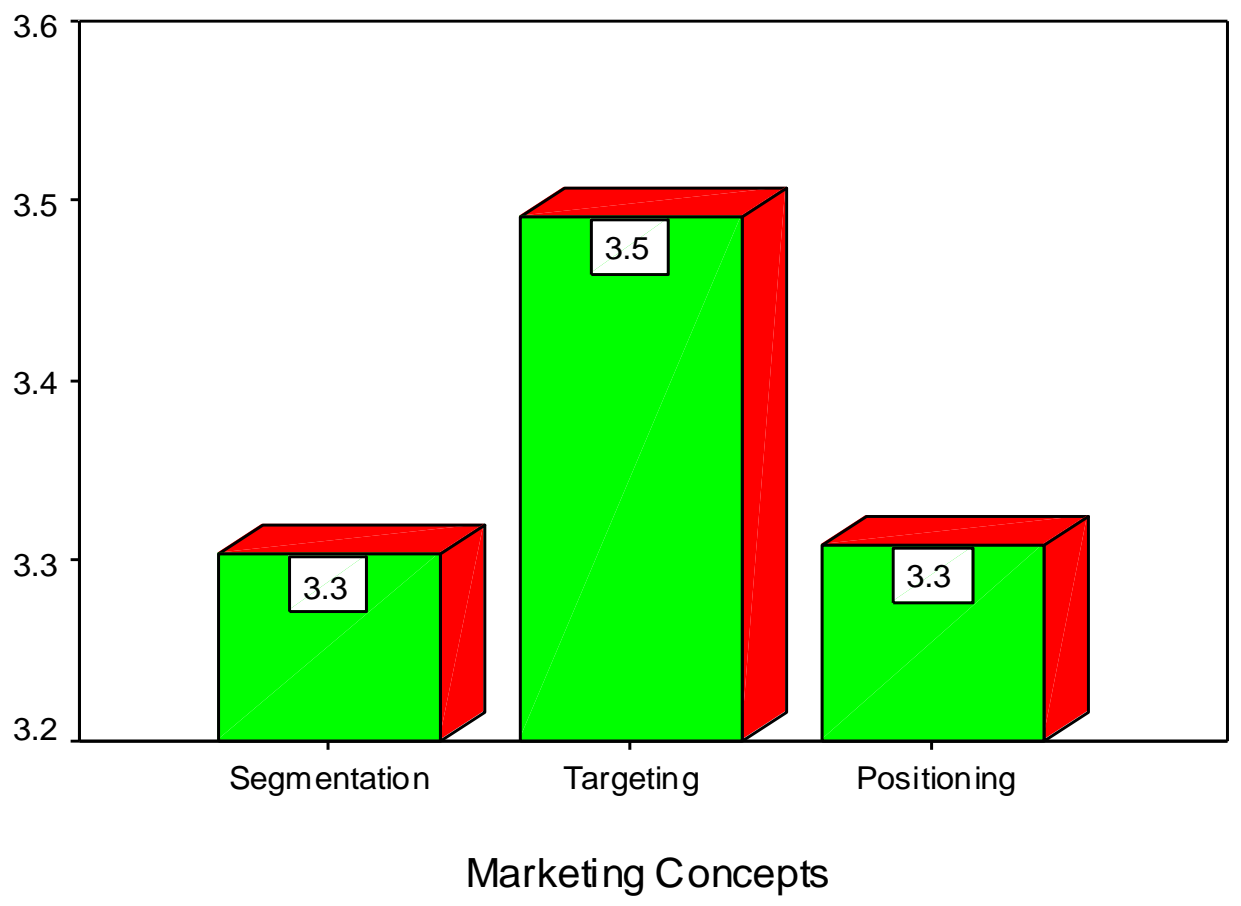

Fig.3:- Bar chart showing the mean score of respondent bank customers on the level of application of marketing concepts by their banks. 


\section{References:-}

1. Adedipe, B. (2000). Universal Banking: International Trends and Experiences. The Nigerian Treasurer, Vol. 9, No. 2 April-June, Pp. 11-15.

2. Adewuyi, I. D. (2011), "Electronic banking in Nigeria: challenges of the regulatory authorities and the way forward", International Journal of Economic Development Research and Investment, Vol. 2 No. 1; April, pp $150-156$.

3. Afolabi, J. A. (2004). "Implications of the Consolidation of Banks for the Nigerian Banking System". NDIC Quarterly, Vol. 14. No. 3, pp 26-44. September.

4. Anyanwu, C.M. (2010). "An Overview of Current Banking Sector Reforms and the Real Sector of the Nigerian Economy", Economic and Financial Review Volume 48/4, December, pp 31 - 56.

5. Areo A. (1992). "Marketing of Banking Services": A case study of Union Bank PLC. (MBA dissertation), O.A.U., Ile-Ife.

6. Areo, A. and S. Eyitayo (2001) Principles and Practice of Marketing Swift Prints Publ. Inc. Nig. pp 10 $-18$

7. Areo, AdebowaleBiodun( 2007). Marketing Practices and Consumer Satisfaction In The Nigerian Banking Industry. Ph.D. Thesis, ObafemiAwolowo University, Ile-Ife.

8. Areo, AdebowaleBiodun (2014) "Early Child Entrepreneurship Development: A Paradigmatic Approach to Unemployment Challenges". PAKISTAN Research in Humanities and Social Sciences, Vol.4 No.4, Pp.41-48. Offshore. Impact Factor (6.35) Index Copernicus. (http://www.journals.savap.org.pk),

9. Areo, AdebowaleBiodun (2014) "Rural Women Involvement in Entrepreneurship in Sukur World Heritage Site, Adamawa State, Nigeria." Asian Journal of Research in Business Economics and Management.ISSN:22497307. INDIA. Offshore Impact factor,Index Copernicus (http://www.aijsh.org

10. Asikhia, O. (2010). "Market-focused strategic flexibility among Nigerian Banks", African Journal of Marketing Management, Vol. 2(2) pp. 018-028, February, pp $18-28$.

11. Bank Services No. 3 Vol. 16, 1982.

12. Bello, K.B. (2006). "Creating Customer Awareness for Banking Services Using Integrated Marketing Communication", Knowledge Review, Vol. 13, No. 7, pp 88 -95.

13. Bello, K.B., Chama, R.S, and Abba, M. (2006). "Customers' Perceptions of post consolidation Banking: A Survey of selected bank customers in Northern Nigeria", Journal of Arid Zone Economy, Vol. 8, No. 1, pp 118 -129 .

14. Berry, L.L. (1983). 'Relationship Marketing', in L.L. Berry et al (eds), Emerging Perspectives of Services Marketing, American Marketing Association, Chicago, IL.

15. Dublow, J. (1992). Occasion used benefit segmentation. Journal of Advertising Research. Mar/April 1118.Zeithami, V., A Parasuraman and L. Berry (1990). Delivering Quality Service. Balancing Consumer Perceptions and Expectations. New York. The Free Press.

16. Ebong, B. B. (2006). "Banking sector reforms: opportunities and challenges, Union Digest, Vol. 10, Nos. 1\&2, $1-9$, June

17. Elumelu, T. (2004), "I foresee an industry with no more than 20 very large and healthy banks". Businessday, Monday, December 27, 2004, p 11

18. Gan C, Cohen D, Clemes M, Chong,E.(2006) A Survey of Customer Retention in the New Zealand Banking Industry: Banks and Bank Systems. 1(4): 83-99.

19. Giese, J. and J. Cote (2000). "Defining Consumer Satisfaction". Academy of Marketing Science Review (Online).

20. Giese, J. and J. Cote (2000). "Defining Consumer Satisfaction". Academy of Marketing Science Review (Online).

21. Gruca, T.S., and Rego.L.L. (2005) "Customer Satisfaction, Cash Flow, and Shareholder Value" Journal of

22. Hunt, S. (2006). The normative imperatives of business and marketing strategy grounding strategy in resourceadvanced theory. Journal of Business and Industrial Marketing of vol. 19, No. 15, April, 2006. Texas Tech University, USA. www.emeralinsight.com/jbim.htm.

23. Koter, P., G. Armstrong, J. Saunders and V. Wong (1999). Principles of Marketing, $2^{\text {nd }}$ European edition, Prentice-Hall, London.

24. Kotler, P \& Armstrong, G. (2004) Principles of marketing: 10th ed, Pearson education Inc. Delhi, India

25. Kotler, P. (1993). Marketing Management: Analysis, Planning, Implementation and Control. $7^{\text {th }}$ Edition. Prince-Hall International, Englewood Cliff, N. Jersey. pp. 13-21

26. Kotler, P. (1997): Marketing Management, Analysis, Planning, Implementation and Control. 9th ed., Prentice Hall Inc., New Jersey. 
27. Kotler, P. (2000). Marketing Management: Analysis, Planning and Control. $11^{\text {th }}$ edition. London, Prentice Hall International.

28. Kotler, P. and S. Levy (1989). "Broadening the Concept of Marketing," Journal of Marketing.pp .10 - 15.

29. Kotler, P., and Keller, K.L. (2006) Marketing Management, Delhi Prentice Hall of India Private Limited.

30. Kotler, P.; G. Armstrong; J. Saunder; and V. Wong (1999). Principles of Marketing. Prentice Hall Europe. London, New York. pp. 150

31. Lees, C. (2005). The Marketing Strategy Performance relationship in an export-driven developing economy; a Korean illustration, International Marketing Review. An ISI ranked journal. Vol. 15, No. 9, August, 2005. Saggand University Seoul, Korea.www.emeraldinsight.com/imr.htm

32. Loveluck, C. and B. Weinberg (1978). Cases in Public and Non-Profit Marketing and Readings in Public and Non-Profit Marketing. Scientific Press, London.Marketing, Vol.69,pp. 115-130.

33. Lewis, B.R,(1982)Weekly Cash-paid Workers :Attitudes and Behaviour with Regard to Banks and otherv financial Institutions. The Marketing of Banking services in European Journal of Marketing. No. 3, VOL.16.

34. Median, A. (1983). "The Roles of Marketing Management in Banking," The Quarterly Review of Marketing.

35. Nunnally, B., D. Plath and E. Nnadozie (2000). Contemporary Banking and Bank Regulation in Nigeria. Journal of International Banking Regulation. Vol. 2, No. 3

36. Nweke, G. (1991). "Current Trends in the International Economic Environment: Challenges and Prospects of the Emerging Economic Environment for Nigerian Economy and the Banking Industry". Financial Institutions Training Centre, Lagos, Nigeria. pp. 64-103.

37. Oboh, G.A.T (2002). "Competition and banking stability in Nigeria", Union Digest, Vol. 7. Nos. 1 \& 2, pp 1-10

38. Oke, M.O. (2012). "Marketing Strategies and Bank Performance in Nigeria: A Post- Consolidation Analysis, Research Journal of Finance and Accounting, Vol. 3, No 5,pp $93-102$.

39. Oni, B. (2002). Capacity Building for Universal Banking: The Challenge of Human Capital Management. The Journal of Banking and Finance. Vol. 5, No. 2, pp 19-24.

40. Osuagwu, L. (2008). Marketing Principles and Management. 3rd edition. Lagos. Grey Resources Limited. pp. 981-1055.

41. Palmer, A., U. McMahon-Beattie and R. Beggs, (2000). A Structural Analysis of Hotel Sector Loyalty Programmes, Journal of Strategic Marketing, Vol. 12, No. 1, pp 54-60

42. Ramesh, P.A (2013) "Marketing Challenges - Bank's financial products" International Journal of Scientific $\begin{array}{llllllll}\text { Research, } & \text { vol. } & 2, & \text { issue } & 1, & \text { pp } & 116 & -\end{array} 117$, http://theglobaljournals.com/ijsr/file.php?val=January_2013_1357052511_0df99_40.pdf (accessesd 25th July, 2013)

43. Ries, A. and J. Trout (1991). Positioning: the battle for your mind. (New York: McGraw Hill Books).

44. Ries, A. and J. Trout (2000). Marketing Warfare (New York: McGraw-Hill).

45. Somoye ROC, (2008). "The performances of commercial banks in post-consolidation period in Nigeria: An empirical review". European Journal of Economics, Finance and Administrative Sciences, issue 14, pp 62 -- 73.

46. Umoren, R. (2006). The Nigerian banking services user's handbook, Global Money Publications, Lagos. British Journal of Marketing Studies Vol.2, No.2, pp.43-53, June 2014 Published by European Centre for Research Training and Development UK (www.ea-journals.org)

47. Uppal, R.K (2010). "Marketing of bank products - emerging challenges \& new strategies", JM International Journal of Management Research, November, pp $35 \quad$-42, http://www.jmijitm.com/papers/130082034035_42.pdf, (accessesd 5th December,2012

48. Wash, S. (2006). Managing and implementation sustain Nance transaction and relationship marketing. International Journal of Bank Marketing. Vol. 17, Vol. April 26,, Dublin Institute of Technology, Northern Ireland, UK. www.eraldinsght.com/ihnbm.htm 